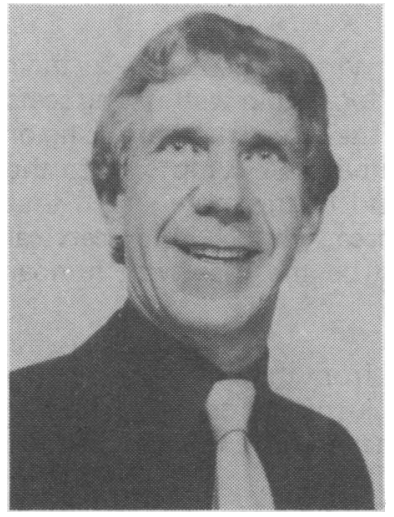

D. Kidd

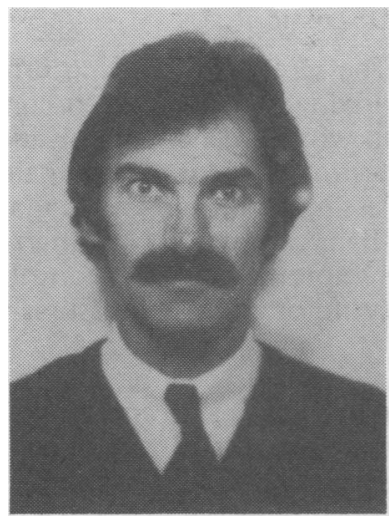

E. M. Winter

\title{
ANNOTATION
}

\section{SOME ANTHROPOMETRIC CHARACTERISTICS OF THE NATIONAL JUNIOR HAMMER SQUAD}

\author{
D. KIDD, BSc, MSc and E. M. WINTER, BEd, MSc
}

Bedford College of Higher Education

\begin{abstract}
A group of five elite young hammer throwers were measured for height, weight, somatotype and body composition. This small group comprised all the potential champions in the UK, selected by the governing body's National Event Coach.

\section{METHODS}

Somatotype and percentage body fat were assessed according to the methods of Heath and Carter (1967) and Durnin and Womersley (1974), respectively.
\end{abstract}

\section{RESULTS}

The results are tabulated and those of Morrow et al 1982) are presented for comparison:
Although the mean values indicate the younger British squad to be slightly taller, lighter and fatter, their ranges, in fact, span the mean American values for each parameter. The throwers, with a mean $16.0 \%$ body fat, are the same order of fatness as non-athletic males, reported by Fox and Mathews (1981) to be $16.8 \%$, although Parizkova (1977) found a mean value of $12 \%$ for the $\mathbf{2 0 - 3 0}$ year-old age range. The hammer throwers are slightly fatter than the elite discus throwers and shot putters measured by Morrow et al (1982), and considerably fatter than javelin throwers, $18.5 \%$, Morrow et al, 1982) and track athletes (6.3-7.5\%, Fox and Mathews, 1981). Winter and Hamley (1976) found a value of $7.4 \% \pm 2.5$ for middle and long distance runners.

\begin{tabular}{|c|c|c|c|}
\hline \multirow[t]{2}{*}{. } & \multicolumn{3}{|c|}{$\begin{array}{c}\text { Young British } \\
\text { Hammer Throwers } \\
\text { (Kidd \& Winter) } n=5\end{array}$} \\
\hline & Mean & S.D. & Range \\
\hline Age (yrs) & 19.0 & 1.7 & $17.2-20.8$ \\
\hline Height (m) & 1.897 & 0.019 & $1.865-1.914$ \\
\hline Weight (kg) & 103.0 & 8.4 & $92.5-114.8$ \\
\hline Fat $(\%)$ & 16.0 & 1.1 & $14.1-16.7$ \\
\hline $\begin{array}{l}\text { Somatotype } \\
\text { Endomorphy }\end{array}$ & 3.1 & 0.4 & $2.5-3.5$ \\
\hline Mesomorphy & 6.0 & 1.0 & $5.0-7.0$ \\
\hline Ectomorphy & 1.2 & 0.8 & $0.5-2.5$ \\
\hline
\end{tabular}

\begin{tabular}{ll}
\multicolumn{3}{c}{ American } \\
Hammer Throwers \\
(Morrow et al) $n=9$ \\
Mean & S.D. \\
24.8 & 3.2 \\
1.873 & 0.031 \\
104.2 & 9.1 \\
15.1 & 4.2
\end{tabular}


The somatotypes found indicate a high level of mesomorphy and confirm previous findings by Tanner (1964) among others, that throwers, like weightlifters and wrestlers, are endomorphic mesomorphs, unlike track athletes and most other top-class sportsmen, who are ectomorphic mesomorphs.

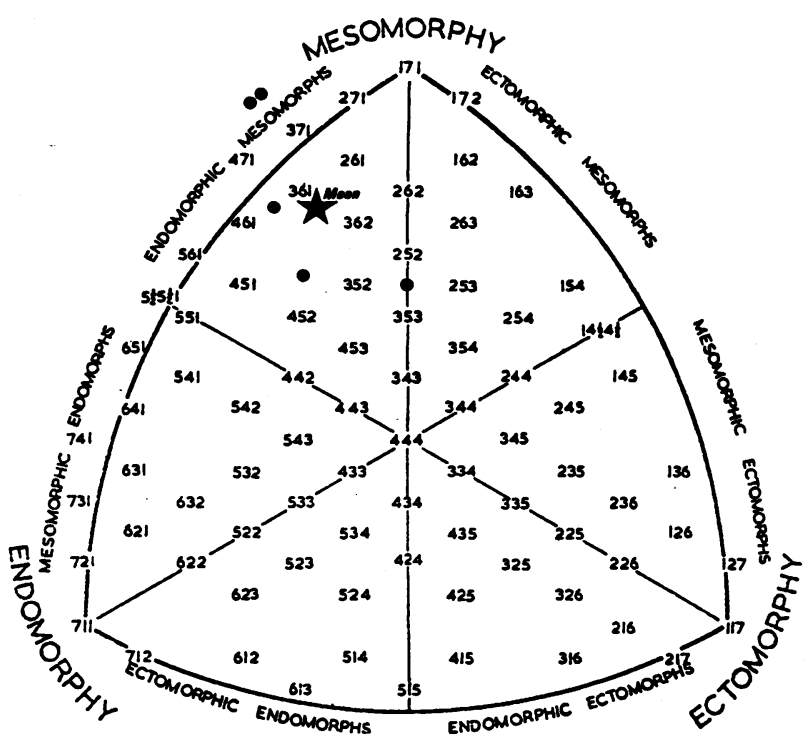

Somatotype distribution of the National Junior Hammer Squad.

\section{REFERENCES}

Dumin, J. V. G. A. and Womersley, J., 1974 "Body fat assessed from total body density and its estimation from skin fold thickness: measurements on 481 men and women aged from 16 to 72 years". Brit.J.Nutr. 32: 77-97.

Fox, E. L. and Mathews, D. K., 1981. The Physiological Basis of Physical Education and Athletics. 3rd Ed. 514-547. Saunders College Publishing: Philadelphia.

Heath, B. H. and Carter, J. E. L., 1967 "A modified somatotype method". Am.J.Phys.Anthropol. 27 (1): 57-74.

Morrow, J. R. Jr., Disch, J. G., Ward, P. E., Donovan, T. J. III, Katch, F. I., Katch, V. L., Weltman, A. L. and Tellez, T., 1982 "Anthropometric, strength and performance characteristics of American world class throwers". J.Sports Med.\& Phys. Fit. 22 (1): 73-79.

Parizkova, J., 1977. Body Fat and Physical Fitness. 35-36. Martinus Nijhoff: The Hague.

Tanner, J. M., 1964. The Physique of the Olympic Athlete. Allen and Unwin, London.

Winter, E. M. and Hamley, E. J., 1976 "Submaximal oxygen uptake related to fat free mass and lean leg volume in trained runners". Br.J.Sports Med. 10 (4): 223-225. 